\title{
2004 年インド洋津波の発生メカニズムの数值解析的検討
}

\author{
松本浩幸 ${ }^{1} \cdot$ 三个田均 ${ }^{2} \cdot$ 鈴木正憲 $^{3}$
}

\begin{abstract}
地震波ならびに津波から独立に推定された断層モデルを用いて, 2004 年インド洋津波の発生および伝播過程の詳細な再 現計算を行い，M9 クラスの海溝型地震により発生する津波像を明らかにした．それぞれの断層モデルから計算される津波 は, すべり量の違いにより波高に差異が見られた．さらに断層運動の動的効果ならびに破壞伝播の影響を調べるために津波 計算の初期条件を変化させた。 その結果，インド洋を伝播する津波への断層の動的効果の寄与は小さいが，断層面の破壊領 域が大きいため断層の破壊過程が津波の到達時刻に影響することが明らかとなった.
\end{abstract}

\section{1.はじめに}

2004 年 12 月 26 日に発生したスマトラ島沖地震 (M9.0)により発生した津波は，インド洋沿岸諸国に未 曾有の被害をもたらした。この 2004 年インド洋津波が 過去に例のない津波災害となった要因として，インド洋 沿岸の津波予警報システムの未整借，あるいはインド洋 では過去に大規模な津波が記録されておらず，そのため 沿岸住民に津波の知識が全くなかったなどの指摘がある (例えば，佐竹 (2006))。また，地震規模が M9 クラス とその震源断層の破壊領域が巨大だったことも被害が広 範囲に及んだ要因と考えられる。

本研究では，地震波ならびに津波から推定された断層 モデルを用いて，インド洋津波の発生および伝播過程の 詳細な再現計算を行う。これは各方面での津波数値計算 を行うにあたり，初期条件の与え方についての検討も必 要なためである。 そして, M9 クラスの海溝型地震によ り発生する津波像を明らかにすることを目的としている.

\section{2004 年インド洋津波の計算モデル}

\section{（1）計算条 件}

本研究では, Ohmachi ら（2001）の断層運動に伴う 動的地盤変位を考慮した津波計算手法を採用する。この 手法では，震源断層を含むインド洋を 3 次元モデル化し て津波の再現計算を行うので, 計算領域をインド洋全体 にとると大容量の計算メモリと膨大な $\mathrm{CPU}$ 時間が要求 される，したがって，計算領域は図-1に示すように， 南緯 $10^{\circ}$, 東経 $80^{\circ}$, および北緯 $20^{\circ}$, 東経 $105^{\circ}$ で囲ま れる範囲とした，津波の差分計算に用いる水深デー夕は, GEBCO One Minute Grid デー夕を 2 分格子間隔に間引 き，時間ステップは $0.5 \mathrm{~s}$ とした。

本研究では，独立したデー夕に基づき提案されている

\footnotetext{
1 正会員 博 (工) (独法) 海洋研究開発機構 海底地震・津波ネットワ 一ク開発部

博(理) 京都大学大学院工学研究科社会基盤工学専攻 京都大学大学院工学研究科社会基盤工学専攻
}

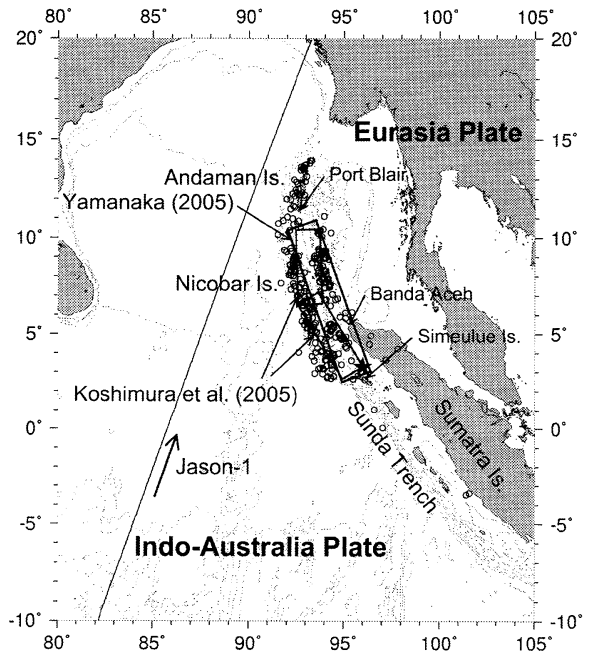

図-1 断層面の位置および津波の再現計算領域（図中の 小さな丸は本震後 24 時間以内に発生した余震)

2 種類の断層モデルから津波の発生と伝播の再現計算を 行い，断層モデルの違いが津波に及ぼす影響を検討した。 さらに，断層運動の動的効果が津波に及ぼす影響につい ても言及する。

\section{（2）地震波から推定された断層モデル}

山中（2005）は，グローバル地震観測網の遠地実体波 を用いてスマトラ島沖地震の震源過程を解析している. その解析結果によると，図-2 に示すように，断層長さ $980 \mathrm{~km}$, 断層幅 $240 \mathrm{~km}$ の断層面内に主要なアスペリテ イが 3 つ存在し, それぞれ破壊開始点付近, 北緯 $5^{\circ}$ 付 近，北緯 $10^{\circ}$ 付近のところに位置する.

本研究では，断層面内のすべりの不均一性を表現する ために，断層の長さ方向 $70 \mathrm{~km}$, 幅方向 $40 \mathrm{~km}$ の 84 の 小断層を設定して，各小断層にすべり量，すべり角，そ して破壞開始時刻を与えることによって，断層面内の不 均一性と破壊伝播速度を表現する。すべり量および破壊 開始時刻は，山中（2005）が推定している地震モーメン 卜解放量拉よびその時刻から算出した。断層の破壊開始 から終了までは 6 分程度を要している。 な㧍各小断層の 


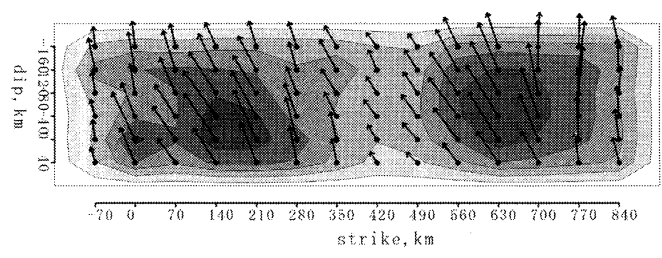

図-2＼cjkstart断層面上のすべりのベクトル分布（山中(2005)）

表-1 山中(2005) と越村ら (2005)の断層モデルの主要パラ メータの比較

\begin{tabular}{|c|c|c|}
\hline & $\begin{array}{l}\text { 山中 }(2005) \text { の断層 } \\
\text { モデル }\end{array}$ & $\begin{array}{l}\text { 越村ら (2005)の断層 } \\
\text { モデル }\end{array}$ \\
\hline 主要基礎デー夕 & 遠地実体波 & $\begin{array}{l}\text { 地殼変動, 人工衛星海 } \\
\text { 面高度デー夕 }\end{array}$ \\
\hline 地震モーメント $M_{0}$ & $3.5 \times 10^{22} \mathrm{Nm}$ & $4.0 \times 10^{22} \mathrm{Nm}$ \\
\hline $\begin{array}{l}\text { モーメントマグニチ } \\
\text { エード } M_{W}\end{array}$ & 9.0 & 9.0 \\
\hline 断層面 (長さ×幅) & $980 \mathrm{~km} \times 240 \mathrm{~km}$ & $\begin{array}{l}500 \mathrm{~km} \times 150 \mathrm{~km} \\
400 \mathrm{~km} \times 150 \mathrm{~km}\end{array}$ \\
\hline 最大すべり量 & $8.9 \mathrm{~m}$ & $11 \mathrm{~m}$ (一様) \\
\hline 破壊継続時間 & $360 \mathrm{~s}$ & $360 \mathrm{~s}$ \\
\hline
\end{tabular}

ライズタイム（すべり継続時間）は $6 \mathrm{~s}$ とした. 図-1 の 本震 24 時間後の余震分布は, 断層面よりもさらに北側 のアンダマン諸島まで拡大している．余震分布と断層面 が重ならないアンダマン諸島の領域は, 地震波解析にお いて直達波と反射フェーズが重なって計算できない領域 である. 本震時における断層破壊領域の北限の議論はこ こでは行わず，山中（2005）が提案した断層モデルにし たがって津波計算を行う.

\section{（3）津波から推定された断層モデル}

一方, 越村ら (2005) は, Harvard 大学の CMT 解の 地震モーメントならびにスマトラ島北西岸の測地データ を矛盾なく説明でき，さらに人工衛星の海面高度データ すなわち津波伝播を比較的よく説明できる断層モデルを 提案している.

断層面は南側と北側の 2 つのセグメントからなり, そ れぞれ断層長さ $500 \mathrm{~km}$ と $400 \mathrm{~km}$ をもち, 断層幅はと もに $150 \mathrm{~km}$ である (図-1). 断層面内のすべりの不均 一性は考慮せずに，すべり量は一様に $11 \mathrm{~m}$ としている. 山中（2005）の断層モデルと同様に，越村ら（2005）の 断層モデルも本震後 24 時間の余震分布とは北限が一致 していない. 先述の地震波から推定された断層モデルと の違いを表-1に示す. 断層面の総面積は山中（2005） の断層モデルの方が大きいが, 越村ら（2005）の断層モ デルは，すべり量が断層面内で $11 \mathrm{~m}$ と一様なためトー タルの地震モーメントは大きくなる.

\section{（4）海底地盤変動}

上述の 2 種類の断層モデルから計算される断層運動に
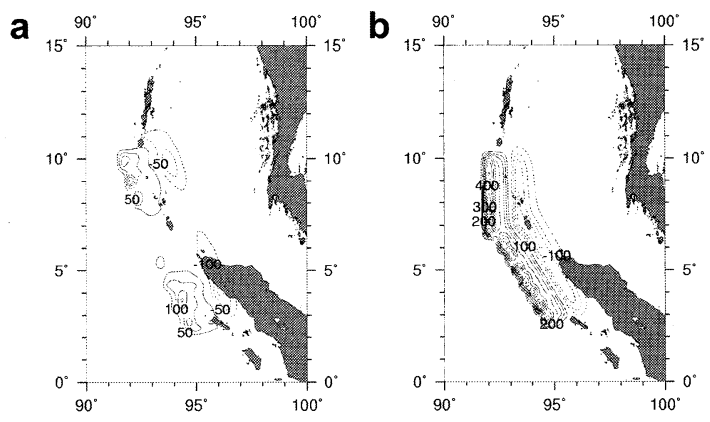

図-3（a）山中 (2005) および, (b) 越村ら (2005)の断層モ デルから計算される地款変動パターン (コンター は50 cm おきで，単位は $\mathrm{cm}$ )

伴う最終的な地款変動パターンを図-3に示す. 図-3(a) が山中（2005）の断層モデルから，図-3(b)が越村ら （2005）の断層モデルから計算される地殼変動パターン である.

図-3(a)の山中（2005）の断層モデルから計算される 地款変動によれば，主要なアスペリティを反映して，北 緯 $5^{\circ}$ 付近のスマトラ島の西方沖, 同 $10^{\circ}$ 付近のニコバル 諸島の西方沖に約 $2 \mathrm{~m} の$ 隆起域が見られる. 山中 （2005）の断層モデルから推定される地殼変動は, スマ トラ島北西端では沈降する一方, ニコバル諸島は, 隆起 域と沈降域の境界線（ヒンジライン）が諸島東側に位置 するため，同諸島は隆起域となる，計算による地款変動 は, 現地フィールド調査や人工衛星画像によって明らか となったスマトラ島 Banda Aceh 市の 0.2〜0.6 m の沈 降, Simeulue 島北側の $1.5 \mathrm{~m}$ の隆起, ならびにPort Blair 検潮所が示唆する $0.9 \mathrm{~m}$ の沈降はほぼ説明できて いる. 一方, ニコバル諸島の全般的な沈降, Simeulue 島南側の数 $10 \mathrm{~cm}$ の沈降を完全には説明できていない.

図-3(b)の越村ら（2005）の断層モデルから計算され る地殼変動は, ニコバル諸島の沈降，スマトラ島北西岸 の 1〜2 $\mathrm{m}$ の沈降を説明できている，地殸変動量につい て, 山中（2005）の断層モデルでは最大隆起量が $2 \mathrm{~m}$ なのに対して，越村ら (2005) の断層モデルでは $4 \mathrm{~m}$ になる. Tanioka ら（2006）はベンガル湾沿岸の検潮記 録の津波データからインバージョンして震源域の地殼変 動量を見積もっているが, インバージョン結果によると スマトラ島の西側の隆起量は $8 \mathrm{~m}$ に達する．津波を説 明できる断層モデル間でも，津波の初期波形に食い違い がある。

\section{3. 津波の再現計算}

\section{（1）津波の発生過程}

山中（2005）の断層モデルから震源断層の破壊過程を 計算して，それを境界条件として海水領域に時々刻々入 


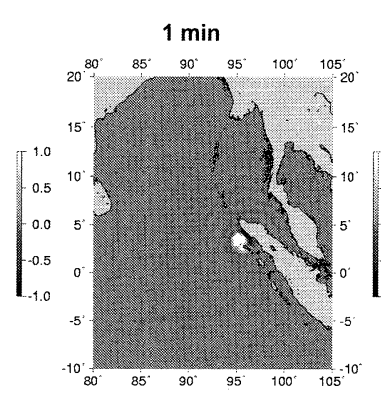

$5 \mathrm{~min}$

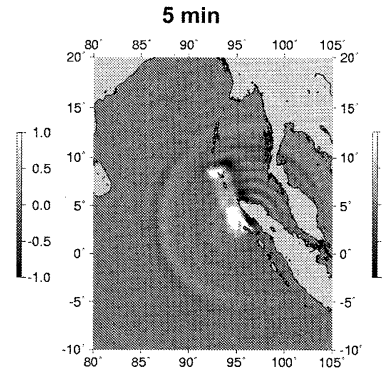

$9 \mathrm{~min}$

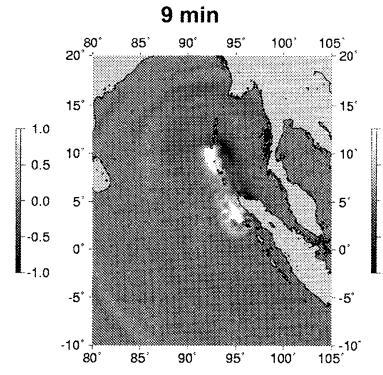

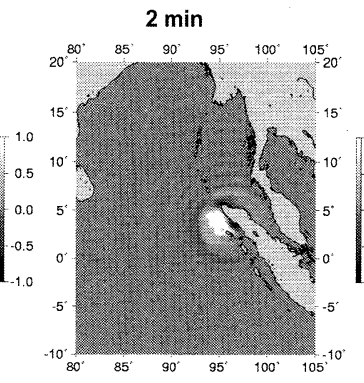

$6 \mathrm{~min}$

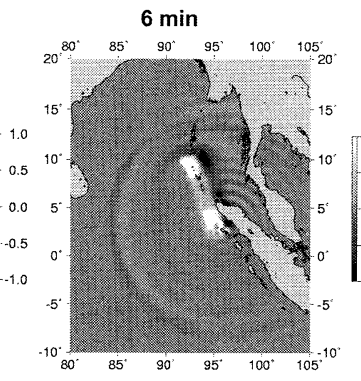

$10 \mathrm{~min}$

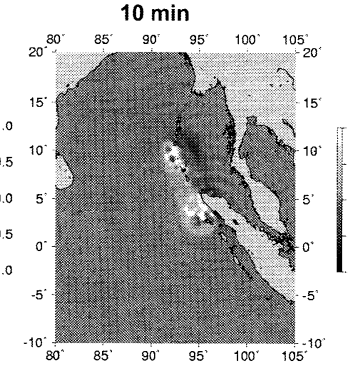

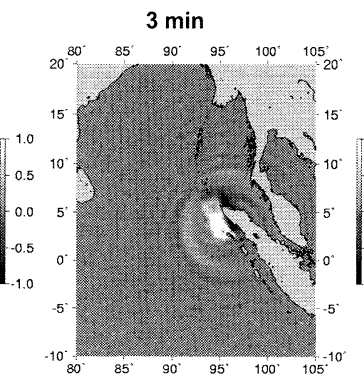

$7 \mathrm{~min}$

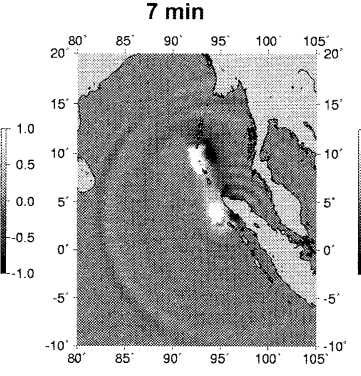

$11 \mathrm{~min}$

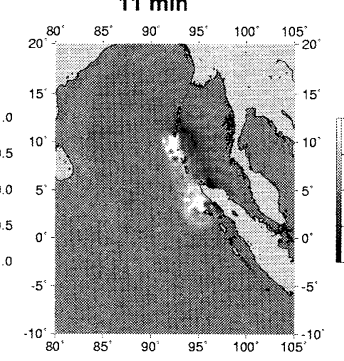

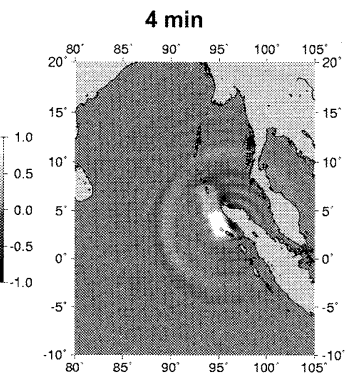

$8 \mathrm{~min}$

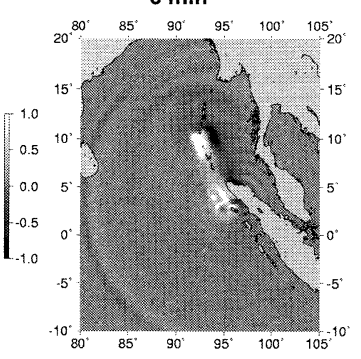

$12 \mathrm{~min}$

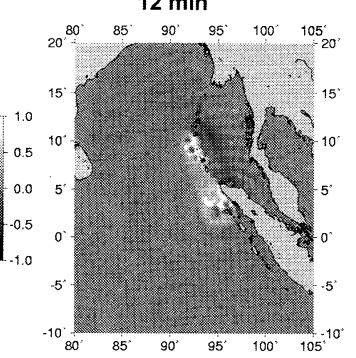

図-4 山中 (2005)の断層モデルから計算した津波発生時の海面変動(時間は断層破壊開始からの経過時間，スケールの単位は m)

力した．その海面の応答，すなわち津波発生時の海面変 動の 1 分おきの状況を図-4 に示す. 1 分後にはスマトラ 島西方沖の震源近傍で地款変動が発生するために, 津波 が発生する. 2 分後には，スマトラ島付近の地殸変動過 程は終了する.図-2に示されているように，すべり量 が小さい領域を経て, 破壊は 5 分後にニコバル諸島に到 達する．5～6 分後に，ニコバル諸島付近のアスペリテ イにより, 北緯 $10^{\circ}$ 付近に波高が大きい津波波源が形成 される. 6 分後に断層破壊が終了するが，その時刻で北 緯 $10^{\circ}$ 付近の津波初期波形は地殼変動とほぼ同じ形状な のに対して, 破壊開始点に近い北緯 $5^{\circ}$ 付近の津波初期 波形は崩れて，津波が伝播している．図-4には，地殸 変動による海面変動とは別の同心円状に先行する波が見 られる.これは小断層のすべりに起因する Rayleigh 波 である．断層の破壊伝播のディレクティビティ効果によ り，その波高は断層の破壊伝播方向で大きくなる.

\section{（2）津波の伝播過程}

津波の伝播状況のスナップショットを 30 分おきに図 -5に示す。図-5 (a) は山中（2005）の断層モデルから計
算した津波伝播，すなわち図 -4 から続く海面変動の状 況である. 震源断層の東側すなわち夕イ側では引き波が 第 1 波となる一方, 西側すなわちスリランカ側では押し 波が第 1 波となる。これはすでに鈴鹿ら（2005）が示し ているように, 山中（2005）の断層モデルから計算され る静的変位を津波波源とする従来手法による計算結果と 同じである. 60 分後の状況を見ると, 津波は北緯 5 付 近と同 $10^{\circ}$ 付近からそれぞれ同心円状に放射している. 山中（2005）は，アスペリテイは3つあると示唆してい るが, 津波の伝播特性から見ると震源付近のアスペリテ イは大まかには1つとして寄与している.

図-5(b)は，比較のために越村ら（2005）の断層モデ ルから計算した津波伝播である. 山中（2005）の断層モ デルに比べて地殼変動量が大きいために，それを反映し て津波の波高も大きい. 断層面内ですべり量が一様な越 村ら（2005）の断層モデルでは, 津波フロントが断層の 走向方向とほぼ平行に伝播する. 断層面の位置は両者は ほぼ重なっているため, 津波つロントの位置は図-5(a) とほほ一致し, タイ方面やスリランカ方面の津波の到達 
a
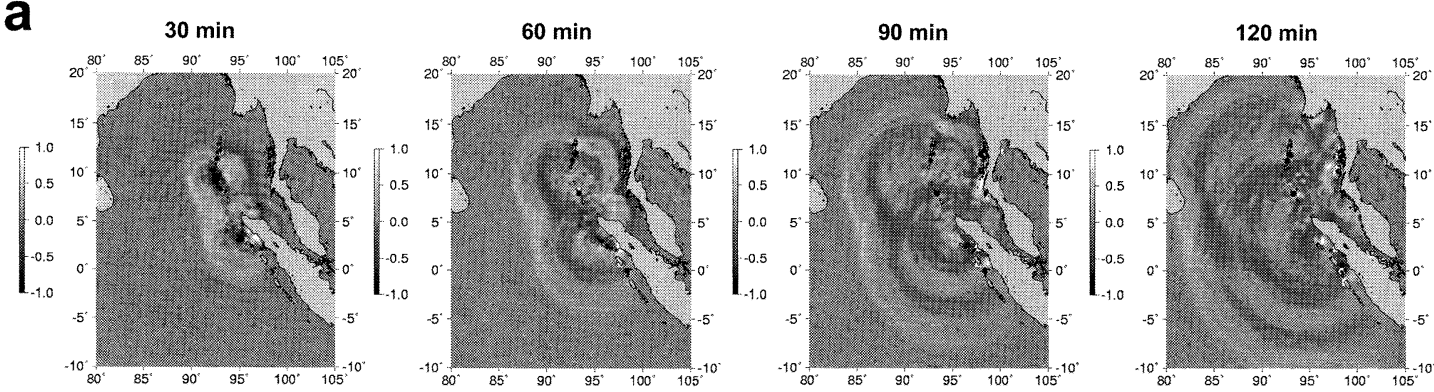

b
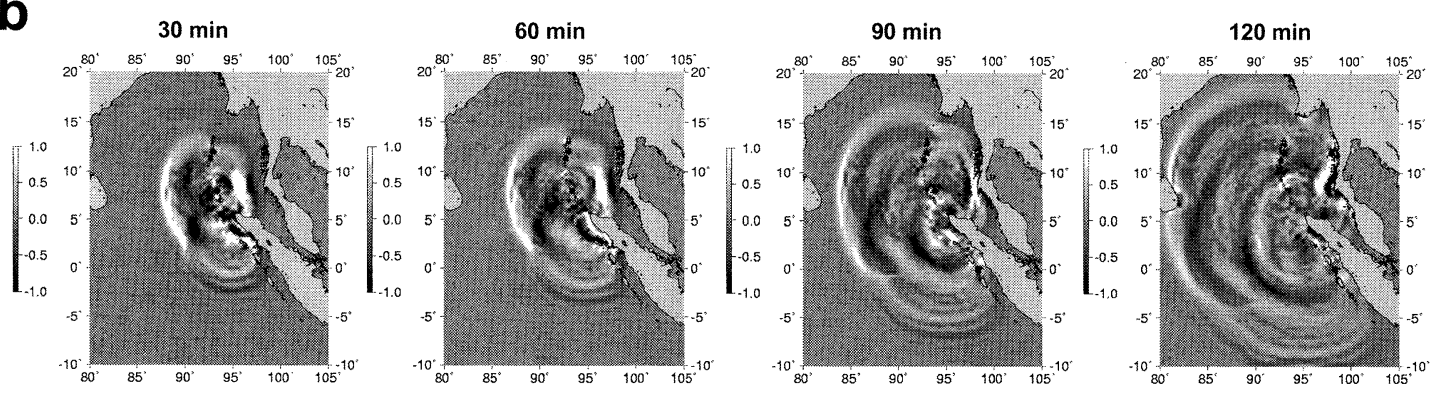

図-5（a)山中 (2005)の断層モデルと (b) 越村ら (2005)の断層モデルから計算される津波伝播(時間は断層破壊開始からの経 過時間，スケールの単位は $\mathrm{m}$ )

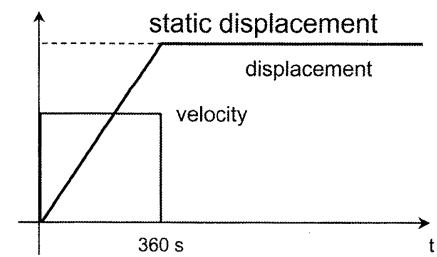

図-6 Model-B に用いる Ramp-time 関数

表-2 動的効果のモデル間の比較

\begin{tabular}{c|c|c}
\hline & 動的地盤変位 & 破壊伝播過程 \\
\hline Model-A & $\bigcirc$ & $\bigcirc$ \\
\hline Model-B & $\bigcirc$ & $\times$ \\
\hline Model-C & $\times$ & $\times$ \\
\hline
\end{tabular}

時刻に差異はない.

\section{4. 断層運動に伴う動的効果の検討}

断層運動の動的破壊が津波に及ぼす影響を，異なる 3 つの境界条件モデルを用いて検討する、ここでは，主と して断層運動に伴い海底地盤が動的に挙動する影響なら びに断層の破壊が進行する影響について検討する．山中 （2005）の断層モデルから計算される動的地盤変位を境 界条件として海水に入力して, 津波を発生・伝播させる 前述の手法 (Model-A) に加えて, 山中（2005）の断層 モデルから計算される最終変位，すなわち図-3(a)を境 界条件とする津波解析も行った (Model-B および Model-C). Model-Bでは，断層破壊に要する時間と等しく なるようにライズタイム $360 \mathrm{~s}$ として，図-6に示すよう な線形の Ramp-time 関数で, 最終変位を空間的に一様 に海水に入力して津波を発生させる.すなわち Model-B では, 破壊伝播速度を無限大と仮定している。し たがって, Model-B は海底地盤の動的挙動の効果は考 慮しているが, 断層の破壊伝播は無視しているモデルと なっている. Model-Cでは, 従来の津波計算手法のよ うに海面に静的かつ同時に最終変位を初期波形として与 える. 以上，3つのモデル間の違いをまとめると表-2の ようになる. Model-A は動的地盤変位と破壊伝播の両 方を考慮, Model-B は動的地盤変位のみ考慮, Model-C は両方とも無視するモデルとなっている.

図-7は，津波到達時間について検討するために, 津 波第 1 波がベンガル湾を伝播している断層破壊開始から 60 分後の津波フロントを比較したものである．津波フ ロントが到達する順序は, 北緯 $4^{\circ}$ 付近を境に, 南側で は Model-C $\rightarrow$ Model-A $\rightarrow$ Model-B であるが, 北側で は Model-C $\rightarrow$ Model-B $\rightarrow$ Model-A と変化する．イン ド洋全体において Model-Cによる津波が先行するのは, 時刻 0 で波源の全体で津波を発生させているためである. 最も現実的な Mode-A の津波フロントが正解值と仮定 すると, 津波波源の南側よりも北側のほうが Model-C 


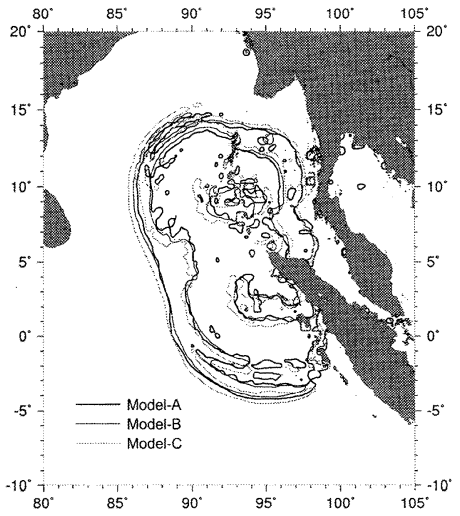

図-7 60分後の津波フロントの比較

との違いが大きい.また Model-A と Model-B の津波 フロントが南北で逆転するのは, Model-B では波源全 体が同時に変動するのに対して, Model-A においては 断層破壊が南東から北西方向に伝播するのを考慮してい るために，南側の断層すべりが発生させる津波が北側の 津波よりも先行するからである．これは，断層の破壊伝 播の影響を無視できないことを示唆している.

次に，津波波高について検討するために，図-1に示 す人工衛星 Jason-1 の軌道断面の波高分布を比較した. 地震発生から 2 時間後に人工衛星 Jason-1 がベンガル湾 上空を飛行し，海面高度計で津波をとらえたえた軌道で ある．津波波高を比較したものを図 -8 に示すが，北緯 $7^{\circ}$ 付近の波高にばらつきがある以外は，モデル間に有意 な差は見られない.すなわち，津波伝播への断層運動の 動的影響はそれほど顕著ではない. 山中（2005）の断層 モデルから計算した津波波高は，人工衛星の海面高度デ 一夕と比較すると，全領域で小さくなっており，北側へ 進むほど位相のずれも大きくなる．図-2 の山中（2005） の断層モデルの南北間のアスペリティのギャップがスマ トラ島北端や夕イ沿岸での津波高さの過小評価につなが るという指摘(松山，私信）とも関連しているのかもしれ ない.

\section{5. おわりに}

本研究では, 動的津波解析手法を 2004 年スマトラ島 沖地震に適用して, インド洋津波の発生過程を検討した。 地震学的に推定された山中（2005）の断層モデルを用い て津波の発生ならびに伝播過程を計算した．断層長さが 約 $1000 \mathrm{~km}$ にも及ぶ地震においては，断層破壊が開始 してから終了するまでに 6 分程度を要した．そのため破

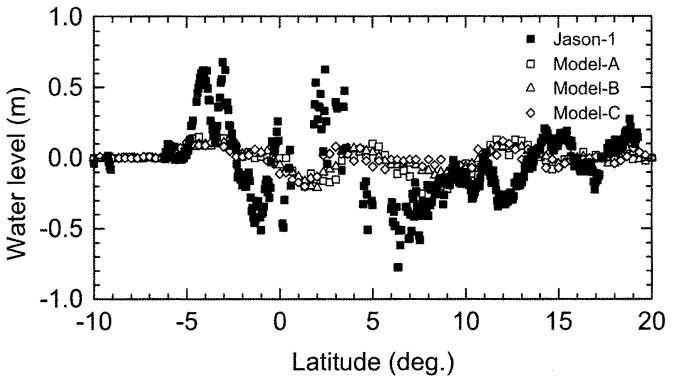

図-8 Jason-1 軌道の津波波高の比較

壊開始点と終了点で津波が発生する時刻に時間差が生じ るため，破壊伝播速度の影響を無視することはできない． しかしながら，津波波源からインド洋を西側に伝播して いく津波への断層破壊の動的な影響は小さい。また地震 波解析とは独立して, 人工衛星の海面高度デー夕の津波 第 1 波を説明できる越村ら（2005）の断層モデルと山中 （2005）の断層モデルとでは，津波の波高に 2 倍近い差 異がある．山中（2005）の断層モデルでは，人工衛星 Jason-1 の海面高度デー夕, すなわち津波波高を説明で きていないので, 地震と津波の両方を合理的に説明でき る断層モデルの作成にはさらに精査が必要である.

謝辞：本研究で用いた断層パラメー夕の一部は, 東京大 学地震研究所山中佳子助手から提供していただいた。 た本論文の執筆にあたり，2006 年 3 月に東京で開催さ れたインド洋津波の数値計算ワークショップでの議論は 有益であった。

\section{参 考 文 献}

越村俊一・高島正典・鈴木進吾・林春男・今村文彦・河田惠昭 (2005)：インド洋に扔ける巨大地震津波災害ポテンシャルの 評価, 海岸工学論文集, 第 52 巻, pp. 1416-1420.

佐竹健治 (2006)：スマトラ沖大地震とインド洋の津波, Japan Geoscience Letters, Vol.1, No.1, pp. 4-6.

鈴鹿陽・高橋智幸・松富英夫 $(2005)$ : 夕イ南西部に来襲したスマ トラ島地震津波の数値解析, 海岸工学論文集, 第 52 卷, pp. 1341-1345

山中佳子 $(2005):$ EIC 地震学ノート, No.161 +.

Ohmachi, T., Tsukiyama, H., Matsumoto, H.(2001) : Simulation of tsunami induced by dynamic displacement of seabed due to seismic faulting, Bull. Seism. Soc. Am., 91, pp. 1898-1909.

Tanioka, Y., Yudhicara, Kusunose, T., Kathiroli, S. Nishimura, Y., Iwasaki, S., Satake, K. (2006) : Rupture process of the 2004 great Sumatra-Andaman earthquake estimated from tsunami waveforms, Earth Planets, Space, Vol. 58, No. 2, pp. 203-209. 